\title{
DEVELOPING AND EVALUATION \\ OF A SHELLING/CRACKING MACHINE SOME \\ AGRICULTURAL PRODUCTS \\ - (SHELLING OF JATROPHA FRUITS)
}

\section{A. M. Mousa*}

\begin{abstract}
This study aims to develop a shelling/cracking machine for dry agricultural products and evaluate performance of developed machine for shelling of Jatropha curcas L. fruits (JCFs) cultivated in Egypt. All shelling experiments of JCFs were carried out at average moisture content of 11.45, 8.48 and $13.89 \%$ (d.b.) for whole fruits, seeds and shells, resp. The results showed that the suggested design of the prototype achieved high efficiency in shelling of JCFs. Under the tested speed range [200 (2.094) to $600 \mathrm{rpm}(6.283 \mathrm{~m} / \mathrm{s})]$ and the tested clearance range [12 to $16 \mathrm{~mm}$ ], the shelling efficiency of JCFs gradually increased with increasing the tested speeds and decreasing the clearances. The speed of $600 \mathrm{rpm}$ is the optimal for the shelling efficiency at clearance of $12 \mathrm{~mm}$. Under the tested sample mass range [250 to $1500 \mathrm{~g}$ ], the results showed that the mass sample of $1000 \mathrm{~g}$ is the optimal for shelling efficiency and productivity of machine, whereas; the mean values of broken seeds percentage (\%-age) were not significant under the tested sample mass range. Also; the results revealed that the highest value of machine productivity was $226.08 \mathrm{~kg} / \mathrm{h}$. Meanwhile; the average values of shelling efficiency, \%-age of broken seeds, unshelled fruits and intact seeds were 95.90, 0.43, 4.10 and $57.93 \%$, resp. Further; the mean values of power consumption and specific energy requirement were $694.95 \mathrm{~W}$ and $3.07 \mathrm{~W} . \mathrm{h} / \mathrm{kg}$, resp. In addition to the level of emitted noise from developed machine was $97.2 \mathrm{~dB}$ and should be reduced to the permissible limits $(90 \mathrm{~dB})$ at exposure period of $8 \mathrm{~h} /$ day.
\end{abstract}

Keywords: Biodiesel sources, Jatropha fruits, shelling/cracking machine, shelling efficiency.

*Lecturer; Agric. Mach. \& Power Eng. Dept.; Fac. of Agric. Eng.; Al-Azhar Univ.;

Cairo; Egypt. E-mail: ahmed_mousa123@azhar.edu.eg 


\section{INTRODUCTION}

$\mathbf{J}$ atropha is one of the renewable energy plants. Its high potential for production of biodiesel fuel from its seeds; reduces dependence on the fossil diesel and provides the country with energy security, in addition to decreasing the environmental pollution from combustion of fossil fuel (Werby and Mousa, 2016).

Jatropha "J" is known with different names such as; physic nut, pinonillo, black vomit nut, purging nut (Barbados) and big purge nut (Salawu et al., 2013). The genus of $\mathrm{J}$. is a perennial plant that belongs to the tribe Joannesieae in the Euphorbiaceae family and contains approximately 170 known species (Kumar and Sharma, 2008). Jatropha varieties which have been identified include $\mathrm{J}$ curcas, J. integerrima and J. gossypifolia; among others. J. curcas has been given the needed attention among the other varieties for its rich source of oil as biofuel (biodiesel) (Krishnan and Paramathma, 2009).

Cramer (2010) mentioned that the dry seeds are containing the oil with percentage ranging from 32 to $40 \%$ by weight. The moisture content of seeds, more than $8 \%$, should be considered too humid and needs more drying. The selection of Jatropha seeds for planting must be at moisture content of around $7 \%$. In case of oil extracting from seeds the moisture content of seeds must be around $6 \%$ (ideally) before pressing. Further; the water content of biofuel norms (straight vegetable oil) should be below $0.08 \%$; because high moisture content in oil might also increase the formation of free fatty acids.

The mean values of the percentages (\%-ages) by weight of Jatropha curcas fruits (JCFs) parts to whole fruit were 66.24, 33.76, 40.85 and $25.39 \%$ for seeds, shells, kernels and husks, resp.; while the mean values of the \%-ages by weight of seed parts to whole seed were 60.84 and $39.16 \%$ for kernels and husks, resp., according to (Werby and Mousa, 2016 and Mousa et al., 2016). Kheiralla et al. (2015) mentioned that the shelling process of JCFs is very important and essential before the oil extraction from JCSs. Pradhan et al. (2010) designed, constructed and tested a hand-operated decorticator of Jatropha fruits for extracting the seeds. Decortication of fruit may be achieved using one of several 
methods: impact, rubbing and squeezing or a combination of the three. In these three methods, the rubbing action would produce seeds with minimal damage. To achieve minimal seeds damage, it is essential to apply least impact with rubbing action. The decorticator can be operated at moisture content of $7.97 \%$ (d.b.) with concave clearance of $21 \mathrm{~mm}$. That gives maximum whole seeds of $67.94 \%$, broken seeds of $2.11 \%$ and machine efficiency of $90.96 \%$. Lim et al. (2014) studied a shelling process on Jatropha fruits for extracting the kernel with two stages of cracking and separation. Both stages used double-level cracking rollers and a blower with ducting as a separation unit. The optimal clearance and air speed for the first stage were $10.5 \mathrm{~mm}$ and $10.0 \pm 0.4 \mathrm{~m} / \mathrm{s}$, resp., whereas the optimal settings for the second stage were $6.0 \mathrm{~mm}$ and $7.5 \pm$ $0.4 \mathrm{~m} / \mathrm{s}$, resp., under these optimal settings; the designed process can achieve $100 \%$ removal of shells and $45.46 \%$ removal of husks while maintaining a low kernel loss of only $2.40 \%$ throughout the stages of the mechanism. Kheiralla et al. (2016) developed and evaluated small scale Jatropha fruits husking machine, consists of frame, feed hopper, fruit husking chamber, concave sieve, rotating blades, discharge outlet and vibrating separator equipped with a sieve for the separation of seeds from the shelling mixture of Jatropha fruits. The shelling process was including compression, shearing and impact principles. The results indicated that the mean values of the husking efficiency, cleaning efficiency, husking capacity, husks percentage and whole seeds percentage were; $100 \%, 91.78 \%, 44.06 \mathrm{~kg} / \mathrm{h}, 34.24 \%$ and $61.99 \%$, resp. at husking and shaker speed of 300 and 60 rpm, resp. Mousa (2015) mentioned that the high consumption of the non-renewable energy sources all over the world, predicted shortage and continuous increasing in its price; further environmental worries. These reasons encouraged to use the sources of renewable energy to replace the fossil fuel such as biofuel. The biofuel includes the following types: solid, liquid and gas, such as: wood pellets, biodiesel or bioethanol and biogas, resp. Biodiesel can be produced from multiple sources such as Jatropha. Jatropha is a small tree that produces fruits on shape of capsules. Fruits contain seeds and each seed contains kernel which has high ratio from non-edible oil as raw material for producing biodiesel via chemical or enzymatic methods 
and it can be used directly in internal combustion engines after mixing with petroleum diesel. For oil extraction with high efficiency and quality from Jatropha, it is necessary shelling of Jatropha fruits for seeds then cracking (husking) seeds for kernels which contain the oil. So; this study aims to develop a shelling/cracking machine for dry agricultural products using locally available materials and performance evaluation of the developed machine for shelling of Jatropha curcas L. fruits cultivated in Egypt.

\section{MATERIALS AND METHODS}

The shelling/cracking machine was constructed in the Workshop of the Fac. of Agric. Eng. during the period from $1^{\text {st }}$ of May 2016 to $30^{\text {th }}$ of Nov. 2016. The shelling experiments of Jatropha curcas fruits "JCFs" were carried out in the Laboratory of Agric. Mech. and Power Eng. Dept., Fac. of Agric. Eng., Al-Azhar Univ., Cairo, Egypt; through the period from $1^{\text {st }}$ of Jan. 2017 to $30^{\text {th }}$ of May 2017.

\subsection{Materials}

\subsubsection{Shelling/Cracking machine}

The main components of the shelling/cracking machine included: frame, feed hopper, shelling/cracking chamber, discharge outlet and source of power, as shown in Fig. 1.

Frame of the machine

The main frame of the machine was constructed from iron channel sections. It is main dimensions were $50 \mathrm{~mm}$ depth, $25 \mathrm{~mm}$ flange width and $5 \mathrm{~mm}$ web thickness, the frame was jointed using helical screws to ease any modification and was fixed on four wheels to facilitate transfer of machine.

Feed hopper

The experimental hopper was constructed from galvanized iron sheet and composed of four sides. These sides were joined with helical screws. The two parallel sides of motor axis were fixed, while the other two sides are crossed and connected with joint from the top for ease articulation motion and control in feed slot. In addition; a gate prevents the fruits before the shelling/cracking chamber. The depth of hopper from top to the gate was $36 \mathrm{~cm}$ and the top area of hopper was $32.0 \mathrm{~cm} \times 21.5 \mathrm{~cm}$. 


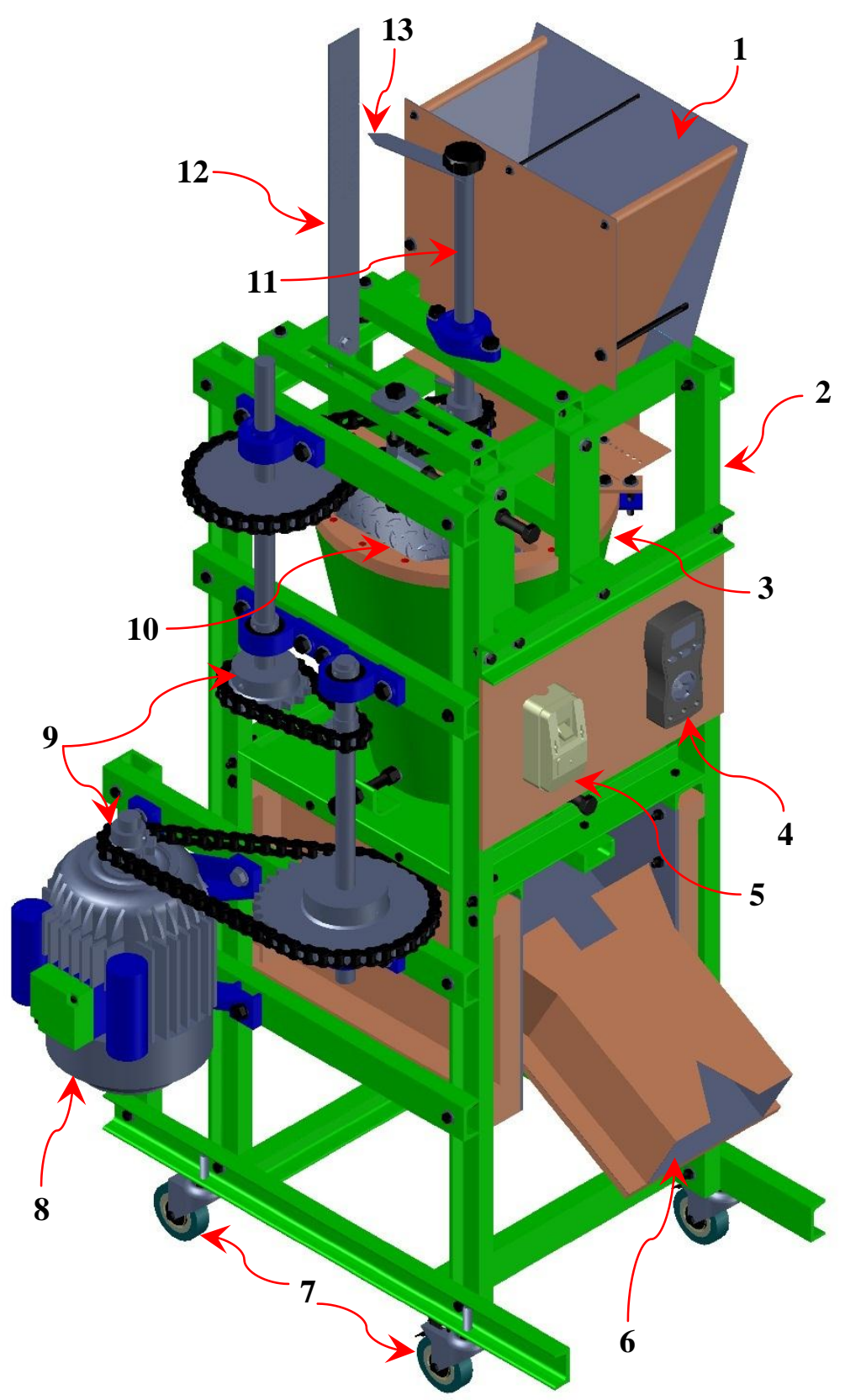

1) Feed hopper, 2) Frame, 3) Shelling chamber, 4) AVO-meter, 5) On/off switch, 6) Discharge outlet, 7) Wheels, 8) Electric motor, 9) Sprocket wheels and chains, 10) Transparent cover, 11) Rotational shaft, 12) scale of clearance and 13) Pointer.

Fig. 1: 3D drawing of developed shelling/cracking machine. 
Shelling/Cracking chamber

The shelling/cracking process in the developed machine depends on friction or rubbing action. The shelling/cracking chamber was composed of: fixed part (external) and rotary part (internal), as shown Fig. 2. The fixed part is conical shaped and made from stainless steel (SS"304") sheet with protrusions (1.6 $\mathrm{mm}$ height) to avoid slipping the fruits or seeds during shelling/cracking process. The conical shape was formed using plate rolling machine then was welded with the following dimensions: $35 \mathrm{~cm}$ upper internal diameter, $20 \mathrm{~cm}$ lower internal diameter and 37.5 $\mathrm{cm}$ depth. The conical part was put into a hollow square plate, in addition to four screws and four parts from steel angle sections to adjust the level of the conical part. The rotary part consists of a conical block in the top and cylindrical block in the bottom. These blocks are made from low carbon steel (mild steel) and turned by lathe machine. The lower block was covered with the same material of fixed conical part. The thickness of sheet without protrusions is $5 \mathrm{~mm}$. Also; the shelling surface was formed using plate rolling machine, then was welded to take

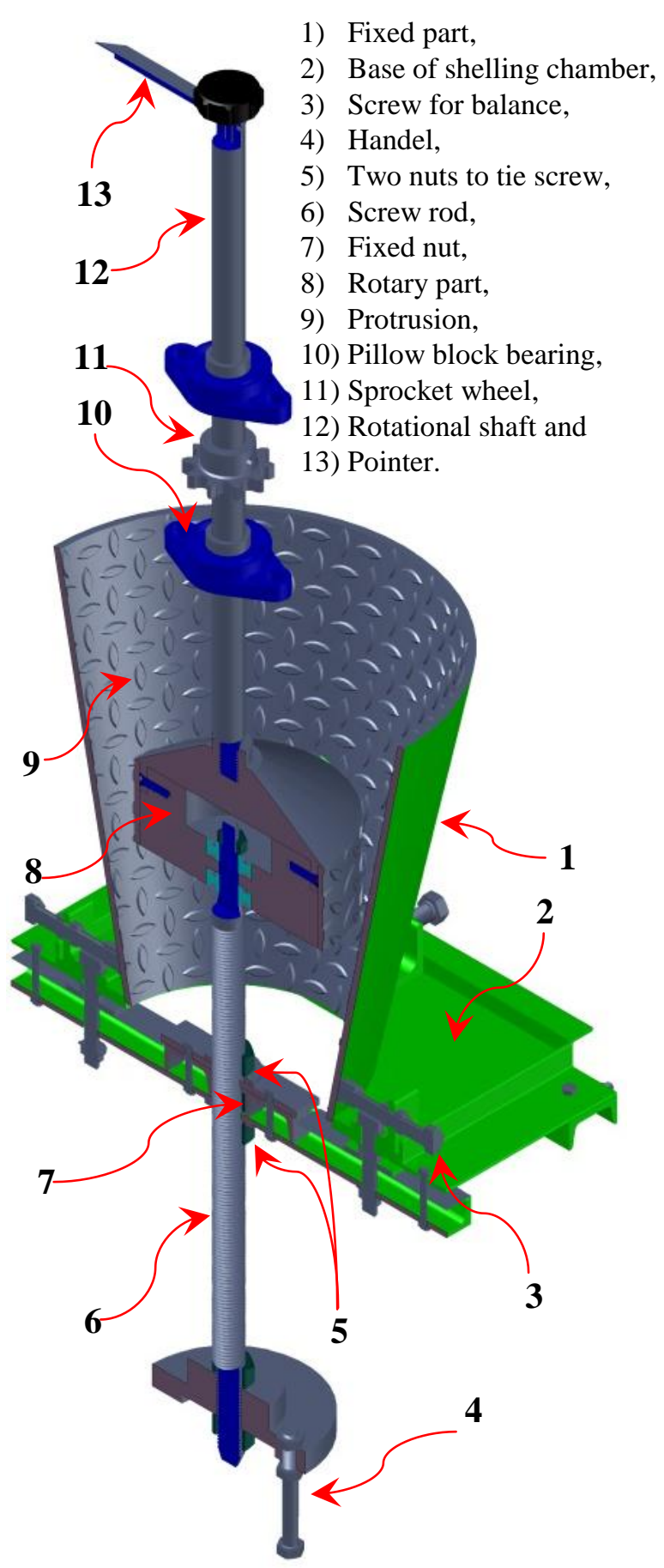

Fig. 2: 3D drawing of longitudinal section of shelling/cracking chamber. 
cylindrical shape with external diameter of $20 \mathrm{~cm}$. The dimensions of fixed conical and rotary parts (friction surfaces) were chosen for the following reasons: Each height of $5 \mathrm{~mm}$ of the rotary part produces increases for the final clearance of $1 \mathrm{~mm}$, to give clearance between two friction surfaces ranging from 0 to $75 \mathrm{~mm}$ and to possibly test of dry agricultural products which need the shelling/cracking. The SS material was used to form the two fraction surfaces for the following reasons: High toughness, acceptable forming and welding, high resistance to corrosion and rusting; in addition to, the SS material is safe for agricultural products.

A screw rod with length of $57.66 \mathrm{~cm}$ was attached with the rotary part from bottom using two thrust ball bearings and was tied using nut into the rotary part. A handle was fitted in the bottom of the screw rod to adjust the required clearance. The screw rod is passed through a fixed nut in steel channel section under the shelling chamber. In addition, two moving nuts were put in the top and bottom of the fixed nut to lock the screw rod after adjusting the required clearance. A smooth rod with diameter of $25 \mathrm{~mm}$ and length of $58.9 \mathrm{~cm}$ was installed in the rotary part from the top through two bearings (FL 205). A pointer was installed above the smooth rod to indicate the value of clearance on a vertical scale, this scale was installed inside the frame at the top.

Discharge outlet

The discharge outlet was installed under the shelling chamber and composed of three parts: two parts were installed vertical into the frame on the two parallel sides of the motor, whose dimensions were $45.5 \mathrm{~cm} \times$ $30.7 \mathrm{~cm}$ for both of them; whereas the other part has an inclination and was put to receive the shelled/cracked material, the dimensions of the inclined part were $61 \mathrm{~cm} \times 25.6 \mathrm{~cm}$ and was installed with two hinges for ease motion and control in the angle of inclination. The discharge outlet was constructed from galvanized iron sheet with thickness of $0.5 \mathrm{~mm}$.

\section{Source of power}

An electric motor "AC" was used to operate the shelling/cracking machine with power of $1.5 \mathrm{~kW}$ and speed of $1400 \mathrm{rpm}$. The power was transmitted to the rotary shaft using sprocket wheels and chains on three stages to reduce the speed of motor to the required speed. 


\subsubsection{Measuring instruments}

1) An electric oven was used to determine the moisture content of fruits, seeds and shells. 2) A digital electric balance with accuracy of $0.01 \mathrm{~g}$ was used to weigh the mass of samples before and after shelling. 3) A digital stopwatch with accuracy of $0.01 \mathrm{~s}$ to measure the time of shelling. 4) A digital Vernier-caliper with accuracy of $0.01 \mathrm{~mm}$ was used to measure the clearance between two friction surfaces and recorded on the clearance scale. 5) A digital tachometer was used to measure the rotational speed "rpm". The specs of tachometer are as follows: Noncontact but; with laser photo, range of the measurement is 2.5 to 99999 rpm and its accuracies are $0.1 \mathrm{rpm}$ through the speed 2.5 to 999.9 and 1 rpm over $1000 \mathrm{rpm}$. 6) A digital AVO-meter was used to measure the consumed electrical current (Amperes " $\mathrm{A} "$ ) during the shelling process. The specs of the device are as follows: accuracy of device is 0.001 , range of the measurement AC/DC voltage up to $600 \mathrm{~V}$ and AC/DC current up to 10 A. 7) A digital Sollatek voltage Stabiliser from type of SVS45-22 was used to regulate and stabilize AC power supply to the motor of machine. 8) A digital sound level meter was used to measure the level of emitted noise "dB" from machine. The specs of the device are as follows: model No. 33-2055 and range of measurement from 50-126 dB. The measuring was carried out in range about of $1 \mathrm{~m}$ horizontal from machine and $1.5 \mathrm{~m}$ vertical from floor (cement concrete) of the Laboratory. The area of Laboratory is $8.20 \mathrm{~m} \times 7.10 \mathrm{~m}$ and its height of $3.80 \mathrm{~m}$.

\subsubsection{Sample of Jatropha fruits}

The Jatropha curcas fruits "JCFs" is one of selected agricultural products to evaluate performance of the developed machine for shelling process. The JCFs were obtained from the Arboretum of the Ministry of Agriculture and Land Reclamation at Dokki; Giza Governorate; Egypt. The dry JCFs were cleaned from any foreign matter, shells and seeds. The moisture content of fruits was determined before conducting of the shelling experiments.

\subsection{Methods}

\subsubsection{The experimental procedure}

The developed machine was evaluated using five clearances (C) were; $12,13,14,15$ and $16 \mathrm{~mm}$. For each clearance, five speeds were tested; 200 (2.094), 300 (3.142), 400 (4.189), 500 (5.236) and $600 \mathrm{rpm}$ (6.283 $\mathrm{m} / \mathrm{s})$. These variables were tested using $250 \mathrm{~g}$ of JCFs with batch system. 
Then; the optimal clearance and speed were constant at study the variable of sample mass. This variable was studied using six masses with batch system, these masses were; 250, 500, 750, 1000, 1250 and $1500 \mathrm{~g}$. The experiments were carried out according the following steps: after adjustment of the required clearance and speed; the known mass of JCFs was poured into the hopper above the gate. Then the machine was switched on and stayed for about one minute. Then the gate of hopper was removed quietly to allow the fruits go to the shelling chamber under the gravity. At the end; the shelling product were carefully collected in collector, then; classified into four categories by manual separation; then weighed. These categories were as follow: unshelled fruits (unshelled whole fruits and partially shelled), intact seeds, broken seeds and shells with dust. At study of the sample mass variable; the feed hopper was removed and replaced with other hopper made from cardboard with lower slot equal about half the upper area of the shelling chamber to determine the maximum feeding rate, the sample mass of JCFs was poured into the shelling chamber through the cardboard hopper and the shelling time was measured at the moment when it reaches the shelled material to half input sample of JCFs by using the balance under the collector. This value was multiplied by 2 to give the total time required for shelling the same input mass in case of continuous feeding. In addition; the consumed current and level of noise released from machine were measured. All experiments were replicated three times.

\subsubsection{Performance evaluation}

\section{- Moisture content:}

The moisture content $\left(M_{C} ;\right.$; \%, d.b.") of fruits, seeds and shells were determined by drying method in a hot air oven at $105^{\circ} \mathrm{C}$ for 24 hours. This test was repeated six times. The moisture content was determined by using the following equation:

$$
M_{C}=\frac{m_{b}-m_{a}}{m_{a}} \times 100 \ldots \ldots \text { (1) }
$$

Where; $m_{b}$ : is the mass of sample before drying $(\mathrm{g})$ and $m_{a}$ : mass of sample after drying $(\mathrm{g})$.

- Performance evaluation:

The following equations were used for the performance evaluation of shelling process according to (Pradhan et al., 2010). 


$$
\begin{gathered}
P_{U}=\frac{M_{U}}{M_{t}} \times 100 \ldots \ldots(2), \quad P_{B S}=\frac{M_{B S}}{M_{t}} \times 100 \ldots \ldots(3), \\
P_{I S}=\frac{M_{I S}}{M_{t}} \times 100 \ldots \ldots(4), \quad P_{S h D}=\frac{M_{S h D}}{M_{t}} \times 100 \ldots \ldots(5), \text { and } \\
\eta_{S h}=\left(1-\frac{M_{U}}{M_{t}}\right) \times 100 \ldots \ldots(6) .
\end{gathered}
$$

Where; $P_{U}$ : is the $\%$-age of unshelled fruits $(\%), M_{U}$ : mass of unshelled fruits $(\mathrm{g}), M_{t}$ : total mass of input fruits $(\mathrm{g}), P_{B S}: \%$-age of broken seeds $(\%), M_{B S}$ : mass of broken seeds (g), $P_{I S}$ : \%-age of intact seeds $(\%), M_{I S}$ : mass of intact seeds $(\mathrm{g}), P_{S h D}$ : \%-age of shells with dust (\%), $M_{S h D}$ : mass of shells with dust (g) and $\eta_{S h}$ : shelling efficiency (\%).

- Shelling capacity (Productivity):

The shelling capacity $(Q$; " $\mathrm{kg} / \mathrm{h}$ ") was calculated according to the following equation:

$$
Q=\frac{\left(M_{t} / 1000\right)}{T} \ldots \ldots \ldots(7)
$$

Where; $T$ : is the time required to shell the sample (h).

- Power and specific energy requirement:

The power requirement of shelling process $(P$; “ $W$ ") was calculated using the following equation:

$$
P=I \times V \times \cos \emptyset \times \eta_{m} \ldots \ldots \ldots \text { (8). }
$$

Where; $P$ : is the total power requirement with load (W), $I$ : current consumed with load (Amperes), $V$ : voltage difference (Volts), $\cos \emptyset$ : power factor assumed $0.80, \emptyset$ : phase angle between current and voltage and $\eta_{m}$ : mechanical efficiency of motor assumed $85 \%$.

The specific energy requirement $\left(E_{S} ;\right.$ " $W . h / k g$ ") was calculated by using the following equation:

$$
E_{S}=\frac{P}{Q} \ldots \ldots(9) .
$$

- The obtained results were statistically analyzed using spread sheet software program: Microsoft Excel and SPSS, V. "23".

\section{RESULTS AND DISCUSSIONS}

All experiments of the shelling for Jatropha curcas fruits (JCFs) were carried out under the average moisture content of $11.45 \pm 1.56$, $8.48 \pm 0.41$ and $13.89 \pm 0.78 \%$ d.b. for whole fruits, seeds and shells, 
resp. The moisture content of used fruits for shelling process is similar to (Ting et al., 2012). They reported that the optimal moisture content for shelling of Jatropha fruits was $9.5 \%$ w.b., this value is close to the moisture content of used fruits in this study of $10.26 \%$ w.b. (11.45\% d.b.).

\section{Effect of speed and clearance on performance indicators}

The shelling mixing of JCFs (Fig. 3) was separated manually to determine all \%-ages of fruits parts as shown in Fig. 4. Table 1 illustrates the average $\%$-ages of Jatropha curcas fruits (JCFs) parts after shelling process at tested five speeds [200 (2.094), 300 (3.142), 400 (4.189), 500 (5.236) and $600 \mathrm{rpm}(6.283 \mathrm{~m} / \mathrm{s})]$. For each speed (S) five clearances (C) were: 12, 13, 14,15 and $16 \mathrm{~mm}$.

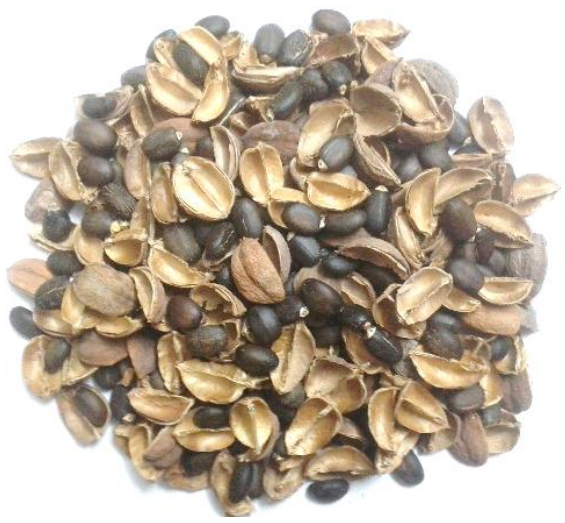

Fig. 3: Final Output after shelling process using the developed machine.

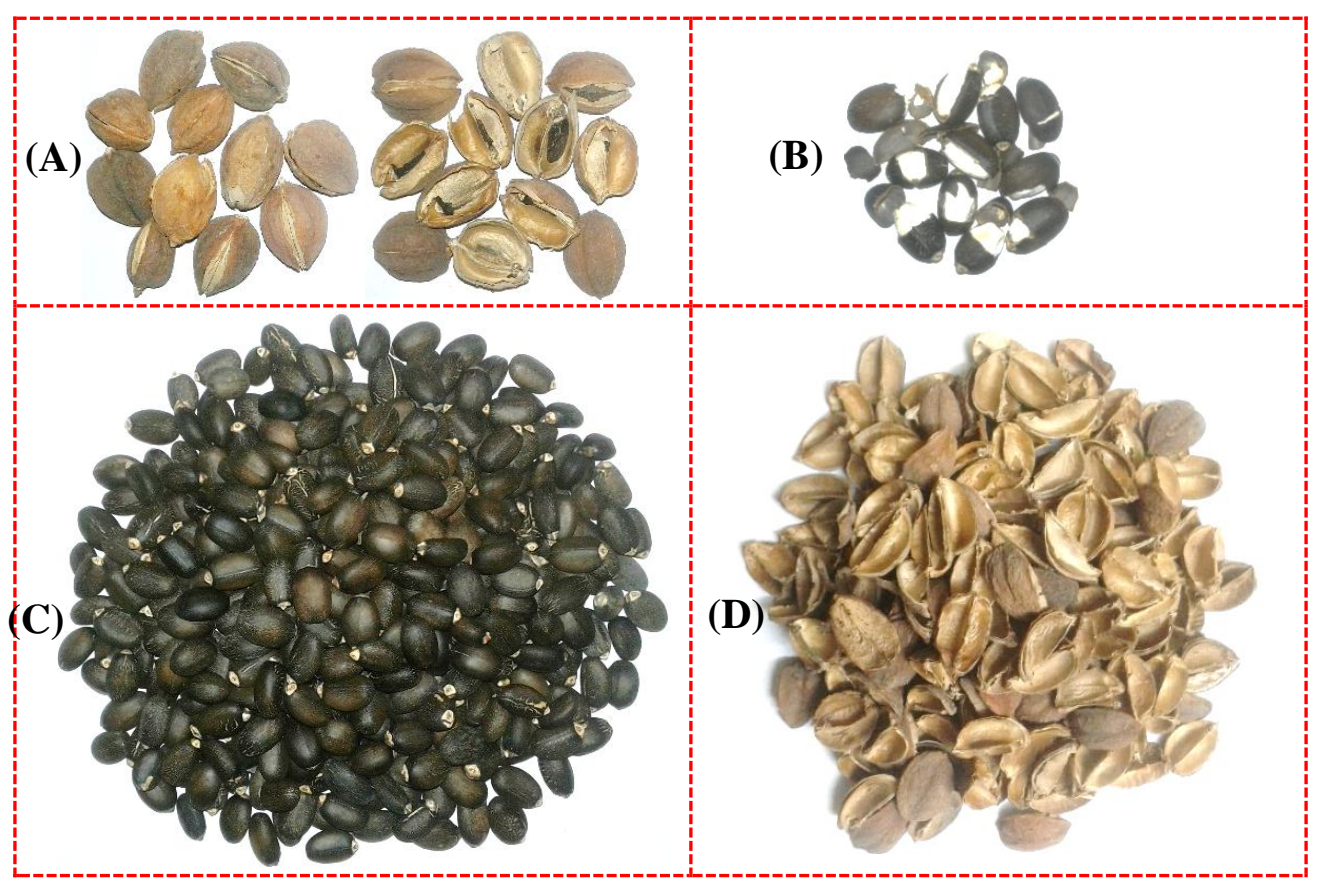

(A): Unshelled fruits "unshelled whole fruits and partially shelled ", (B): Broken seeds, (C): Intact seeds and (D): Shells with dust.

Fig. 4: Parts of JCFs sample after mechanical shelling and manual seprating. 
Table 1: The percentages of JCFs parts after shelling process at tested clearances and speeds (mean value \pm standard deviation).

\begin{tabular}{|c|c|c|c|c|c|}
\hline $\begin{array}{c}\text { S, } \\
(\mathbf{r p m})\end{array}$ & $\begin{array}{c}\mathbf{C}, \\
(\mathbf{m m})\end{array}$ & $\begin{array}{l}\mathbf{P}_{\mathbf{U}}, \\
(\%)\end{array}$ & $\begin{array}{l}\mathbf{P}_{\mathbf{B S}}, \\
(\%)\end{array}$ & $\begin{array}{l}P_{I S}, \\
(\%)\end{array}$ & $\begin{array}{c}\mathbf{P}_{\text {ShD }}, \\
(\%)\end{array}$ \\
\hline \multirow{5}{*}{200} & 12 & $13.70 \pm 2.21$ & $0.64 \pm 0.41$ & $51.11 \pm 1.29$ & $33.71 \pm 1.27$ \\
\hline & 13 & $21.05 \pm 1.15$ & $0.36 \pm 0.29$ & $48.00 \pm 1.56$ & $29.72 \pm 0.38$ \\
\hline & 14 & $26.11 \pm 2.96$ & $0.09 \pm 0.10$ & $46.58 \pm 1.73$ & $26.42 \pm 1.23$ \\
\hline & 15 & $35.93 \pm 3.81$ & $0.16 \pm 0.13$ & $40.38 \pm 2.49$ & $22.64 \pm 1.53$ \\
\hline & 16 & $55.85 \pm 0.80$ & $0.09 \pm 0.16$ & $29.04 \pm 1.01$ & $14.09 \pm 0.23$ \\
\hline \multirow{5}{*}{300} & 12 & $9.06 \pm 1.22$ & $0.33 \pm 0.04$ & $54.54 \pm 0.06$ & $35.44 \pm 1.24$ \\
\hline & 13 & $13.68 \pm 1.73$ & $0.26 \pm 0.15$ & $52.05 \pm 0.89$ & $33.13 \pm 0.77$ \\
\hline & 14 & $19.47 \pm 1.30$ & $0.01 \pm 0.02$ & $49.89 \pm 0.62$ & $29.74 \pm 1.27$ \\
\hline & 15 & $26.19 \pm 4.86$ & $0.14 \pm 0.14$ & $46.20 \pm 2.30$ & $26.70 \pm 2.55$ \\
\hline & 16 & $37.68 \pm 2.58$ & $0.00 \pm 0.00$ & $40.21 \pm 1.86$ & $21.33 \pm 0.65$ \\
\hline \multirow{5}{*}{400} & 12 & $5.06 \pm 1.73$ & $0.64 \pm 0.59$ & $55.86 \pm 1.12$ & $37.80 \pm 0.96$ \\
\hline & 13 & $10.83 \pm 2.60$ & $0.42 \pm 0.34$ & $53.81 \pm 1.57$ & $34.10 \pm 0.78$ \\
\hline & 14 & $13.96 \pm 3.56$ & $0.19 \pm 0.18$ & $52.78 \pm 2.61$ & $32.50 \pm 1.35$ \\
\hline & 15 & $17.35 \pm 1.21$ & $0.00 \pm 0.00$ & $51.64 \pm 0.22$ & $30.02 \pm 0.69$ \\
\hline & 16 & $32.48 \pm 3.67$ & $0.00 \pm 0.00$ & $42.54 \pm 2.64$ & $24.16 \pm 1.20$ \\
\hline \multirow{5}{*}{500} & 12 & $3.46 \pm 2.04$ & $0.58 \pm 0.53$ & $56.46 \pm 0.39$ & $38.51 \pm 1.35$ \\
\hline & 13 & $5.59 \pm 0.46$ & $0.30 \pm 0.27$ & $56.48 \pm 0.20$ & $36.80 \pm 0.26$ \\
\hline & 14 & $11.82 \pm 2.12$ & $0.10 \pm 0.13$ & $52.46 \pm 1.09$ & $34.05 \pm 0.76$ \\
\hline & 15 & $18.02 \pm 3.15$ & $0.00 \pm 0.00$ & $49.58 \pm 1.51$ & $31.58 \pm 1.70$ \\
\hline & 16 & $23.65 \pm 2.65$ & $0.00 \pm 0.00$ & $47.64 \pm 2.09$ & $27.56 \pm 0.40$ \\
\hline \multirow{5}{*}{600} & 12 & $1.41 \pm 1.36$ & $0.51 \pm 0.50$ & $58.07 \pm 0.99$ & $39.16 \pm 0.95$ \\
\hline & 13 & $4.12 \pm 0.28$ & $0.19 \pm 0.22$ & $56.40 \pm 1.05$ & $38.34 \pm 0.77$ \\
\hline & 14 & $5.94 \pm 1.53$ & $0.12 \pm 0.21$ & $55.70 \pm 1.40$ & $37.33 \pm 0.94$ \\
\hline & 15 & $9.65 \pm 2.05$ & $0.00 \pm 0.00$ & $54.14 \pm 1.68$ & $35.34 \pm 0.72$ \\
\hline & 16 & $17.4 \pm 2.13$ & $0.05 \pm 0.09$ & $50.65 \pm 1.58$ & $31.13 \pm 1.00$ \\
\hline
\end{tabular}

For the \%-age of unshelled fruits: The results showed that the unshelled fruits decreased with increasing the speed and decreasing the clearance. The \%-age of unshelled fruits decreased from 17.4 to $1.41 \%$ at speed of $600 \mathrm{rpm}, 23.65$ to $3.46 \%$ at speed of $500 \mathrm{rpm}, 32.48$ to $5.06 \%$ at speed of $400 \mathrm{rpm}, 37.68$ to $9.06 \%$ at speed of $300 \mathrm{rpm}$ and 55.85 to $13.70 \%$ at speed of $200 \mathrm{rpm}$ when decreasing the clearance from 16 to $12 \mathrm{~mm}$ as shown in Table 1. The Duncan Multiple-Range Test (DMRT) in Table 2 showed that the mean effect of speed on the \%-age of unshelled fruits. The mean values of unshelled fruits decreased significantly (at $5 \%$ level "P < 0.05 ") from 30.53 to $7.71 \%$ with increasing the speed from 200 to $600 \mathrm{rpm}$. Also; Table 3 shows the result of Duncan's test for the mean 
effect of clearance on the \%-age of unshelled fruits. The mean values of unshelled fruits decreased significantly (at 5\% level "P < 0.05 ") from 33.42 to $6.54 \%$ with decreasing the clearance from 16 to $12 \mathrm{~mm}$.

Table 2: Duncan's test for the mean of effect of tested speeds on \%-age of Jatropha fruits parts.

\begin{tabular}{ccccc}
\hline $\mathbf{S},(\mathbf{r p m})$ & $\mathbf{P}_{\mathbf{U}},(\boldsymbol{\%})$ & $\mathbf{P}_{\mathbf{B S}},(\boldsymbol{\%})$ & $\mathbf{P}_{\mathbf{I S}},(\boldsymbol{\%})$ & $\mathbf{P}_{\mathbf{S h D}},(\boldsymbol{\%})$ \\
\hline $\mathbf{2 0 0}$ & $30.53^{\mathrm{e}}$ & $0.27^{\mathrm{a}}$ & $43.02^{\mathrm{a}}$ & $25.32^{\mathrm{a}}$ \\
$\mathbf{3 0 0}$ & $21.21^{\mathrm{d}}$ & $0.15^{\mathrm{a}}$ & $48.58^{\mathrm{b}}$ & $29.27^{\mathrm{b}}$ \\
$\mathbf{4 0 0}$ & $15.94^{\mathrm{c}}$ & $0.25^{\mathrm{a}}$ & $51.32^{\mathrm{c}}$ & $31.72^{\mathrm{c}}$ \\
$\mathbf{5 0 0}$ & $12.51^{\mathrm{b}}$ & $0.20^{\mathrm{a}}$ & $52.53^{\mathrm{d}}$ & $33.70^{\mathrm{d}}$ \\
$\mathbf{6 0 0}$ & $7.71^{\mathrm{a}}$ & $0.17^{\mathrm{a}}$ & $54.99^{\mathrm{e}}$ & $36.26^{\mathrm{e}}$ \\
\hline
\end{tabular}

Table 3: Duncan's test for the mean of effect of tested clearances on $\%$-age of Jatropha fruits parts.

\begin{tabular}{ccccc}
\hline $\mathbf{C}, \mathbf{( m m})$ & $\mathbf{P}_{\mathbf{U}},(\boldsymbol{\%})$ & $\mathbf{P}_{\mathbf{B S}},(\boldsymbol{\%})$ & $\mathbf{P}_{\mathbf{I S}},(\boldsymbol{\%})$ & $\mathbf{P}_{\mathbf{S h D}},(\boldsymbol{\%})$ \\
\hline $\mathbf{1 2}$ & $6.54^{\mathrm{a}}$ & $0.54^{\mathrm{c}}$ & $55.21^{\mathrm{e}}$ & $36.92^{\mathrm{e}}$ \\
$\mathbf{1 3}$ & $11.05^{\mathrm{b}}$ & $0.31^{\mathrm{b}}$ & $53.35^{\mathrm{d}}$ & $34.42^{\mathrm{d}}$ \\
$\mathbf{1 4}$ & $15.46^{\mathrm{c}}$ & $0.10^{\mathrm{a}}$ & $51.48^{\mathrm{c}}$ & $32.01^{\mathrm{c}}$ \\
$\mathbf{1 5}$ & $21.43^{\mathrm{d}}$ & $0.06^{\mathrm{a}}$ & $48.39^{\mathrm{b}}$ & $29.26^{\mathrm{b}}$ \\
$\mathbf{1 6}$ & $33.42^{\mathrm{e}}$ & $0.03^{\mathrm{a}}$ & $42.01^{\mathrm{a}}$ & $23.65^{\mathrm{a}}$ \\
\hline
\end{tabular}

For the \%-age of broken seeds: Generally; the broken seeds increased with decreasing the clearance for all the speeds. Duncan's test in Table 2 showed that the mean effect of speed on the \%-age of broken seeds. The mean values of broken seeds were not significantly affected (at $5 \%$ level "P > 0.05"). Also; Table 3 shows the result of Duncan's test for the mean effect of clearance on the \%-age of broken seeds. The mean values of broken seeds increased with decreasing the clearance but; the mean values of broken seeds increased significantly from 0.10 to $0.54 \%$ with decreasing the clearance from 14 to $12 \mathrm{~mm}$. Pradhan et al. (2010) mentioned that the $\%$-age of broken seeds was $2.11 \pm 1.56 \%$ at moisture content of $7.97 \%$ (d.b.) for mechanical shelling of Jatropha fruits. Whereas the mean highest value of $\%$-age of broken seeds was $0.54 \%$ and equal $1.35 \mathrm{~g}$ from mass used of sample $(250 \mathrm{~g})$ in shelling process. This mass $(1.35 \mathrm{~g})$ is about of 2 to 3 seeds. Also; the values of $\%$-age of broken seeds in Table 1 are small for used sample mass and not exceed of $1 \%$ so; don't take in consideration, in addition; must be investigate of effect of sample mass on the \%-age of broken seeds and shelling efficiency. 
For the \%-age of intact seeds: The obtained results indicated that the intact seeds increased with decreasing the tested clearance and increasing the speed. The \%-age of intact seeds increased from 29.04 to $51.11 \%$ at speed of $200 \mathrm{rpm}$, from 40.21 to $54.54 \%$ at speed of $300 \mathrm{rpm}$, from 42.54 to $55.86 \%$ at speed of $400 \mathrm{rpm}$, from 47.64 to $56.46 \%$ at speed of 500 $\mathrm{rpm}$, and from 50.65 to $58.07 \%$ at speed of $600 \mathrm{rpm}$ when decreasing the clearance from 16 to $12 \mathrm{~mm}$ as shown in Table 1. Duncan's test as shown in Table 2 showed that the mean effect of speed on the \%-age of intact seeds. The mean values of intact seeds increased significantly (at 5\% level "P < 0.05 ") from 43.02 to $54.99 \%$ with increasing the speed from 200 to $600 \mathrm{rpm}$. Also; Table 3 shows the result of Duncan's test for the mean effect of clearance on the \%-age of intact seeds. The mean values of intact seeds increased significantly (at 5\% level "P < 0.05 ") from 42.01 to $55.21 \%$ with decreasing the clearance from 16 to $12 \mathrm{~mm}$.

For the \%-age of shells with dust: The results showed that the \%-age of shells with dust increased with decreasing the tested clearance and increasing the tested speed. The $\%$-age of shells with dust increased from 14.09 to $33.71 \%$ at speed of $200 \mathrm{rpm}$, from 21.33 to $35.44 \%$ at speed of $300 \mathrm{rpm}$, from 24.16 to $37.80 \%$ at speed of $400 \mathrm{rpm}$, from 27.56 to $38.51 \%$ at speed of $500 \mathrm{rpm}$ and from 31.13 to $39.16 \%$ at speed of 600 rpm when decreasing the clearance from 16 to $12 \mathrm{~mm}$ as shown in Table 1. Duncan's test in Table 2 showed that the mean effect of speed on the $\%$-age of shells with dust. The mean values of shells with dust increased significantly (at 5\% level "P < 0.05 ") from 25.32 to $36.26 \%$ with increasing the tested speed from 200 to $600 \mathrm{rpm}$. Also; Table 3 shows the result of Duncan's test for the mean effect of clearance on the \%-age of shells with dust. The mean values of shells with dust increased significantly (at $5 \%$ level "P $<0.05$ ") from 23.65 to $36.92 \%$ with decreasing the clearance from 16 to $12 \mathrm{~mm}$.

For shelling efficiency: Fig. 5 shows the relationship between shelling efficiency (\%) and rotational speed [200 (2.094), 300 (3.142), 400 (4.189), $500(5.236)$ and $600 \mathrm{rpm}(6.283 \mathrm{~m} / \mathrm{s})]$ under five clearances [12, $13,14,15$, and $16 \mathrm{~mm}$. Generally; the shelling efficiency of $\mathrm{JCF}_{\mathrm{S}}$ gradually increased with increasing the tested speeds and decreasing the clearances. From Table 4, the highest value of shelling efficiency was 
$98.59 \pm 1.36 \%$ at speed of $600 \mathrm{rpm}(6.283 \mathrm{~m} / \mathrm{s})$ and clearance of $12 \mathrm{~mm}$; whereas the lowest value of shelling efficiency was $44.15 \pm 0.80 \%$ at speed of $200 \mathrm{rpm}(2.094 \mathrm{~m} / \mathrm{s})$ and clearance of $16 \mathrm{~mm}$.

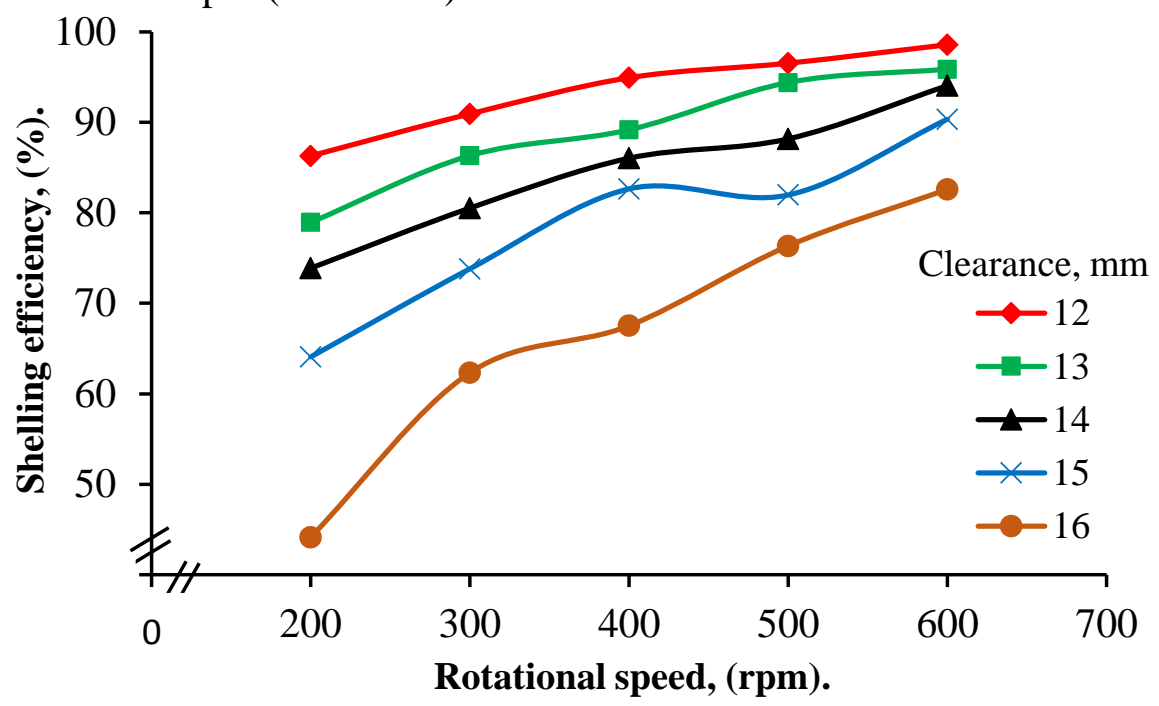

Fig. 5: Effect of the tested rotational speed on the shelling efficiency at different clearances.

Duncan's tests in Table 4 showed that the mean effect of speed on the shelling efficiency (\%). The mean values of shelling efficiency increased significantly (at 5\% level "P < 0.05 ") from 69.47 to $92.29 \%$ with increasing the speed from 200 to $600 \mathrm{rpm}$. Also; the result of Duncan's test showed that the mean effect of clearance on the shelling efficiency. The mean values of shelling efficiency increased significantly (at 5\% level "P < 0.05 ") from 66.59 to $93.46 \%$ with decreasing the clearance from 16 to $12 \mathrm{~mm}$.

Table 4: Values of shelling efficiency at tested speeds and clearances (mean value \pm standard deviation) and result of Duncan's test.

\begin{tabular}{|c|c|c|c|c|c|c|}
\hline \multirow{3}{*}{$\underset{(\mathbf{r p m})}{\mathbf{S},}$} & \multicolumn{5}{|c|}{ Shelling efficiency, (\%) } & \multirow[b]{3}{*}{ Mean } \\
\hline & \multicolumn{5}{|c|}{$\mathrm{C},(\mathbf{m m})$} & \\
\hline & 12 & 13 & 14 & 15 & 16 & \\
\hline 200 & $86.30 \pm 2.21$ & $78.95 \pm 1.15$ & $73.89 \pm 2.96$ & $64.07 \pm 3.81$ & $44.15 \pm 0.80$ & $69.47^{\mathrm{e}}$ \\
\hline 300 & $90.94 \pm 1.22$ & $86.32 \pm 1.73$ & $80.53 \pm 1.30$ & $73.81 \pm 4.86$ & $62.32 \pm 2.58$ & $78.78^{d}$ \\
\hline 400 & $94.94 \pm 1.73$ & $89.17 \pm 2.60$ & $86.04 \pm 3.56$ & $82.65 \pm 1.21$ & $67.52 \pm 3.67$ & $84.06^{c}$ \\
\hline 500 & $96.54 \pm 2.04$ & $94.41 \pm 0.46$ & $88.18 \pm 2.12$ & $81.98 \pm 3.15$ & $76.35 \pm 2.65$ & $87.49^{b}$ \\
\hline 600 & $98.59 \pm 1.36$ & $95.88 \pm 0.28$ & $94.06 \pm 1.53$ & $90.35 \pm 2.05$ & $82.59 \pm 2.13$ & $92.29^{a}$ \\
\hline Mean & $93.46^{a}$ & $\mathbf{8 8 . 9 5}^{\mathrm{b}}$ & $84.54^{c}$ & $78.57^{\mathrm{d}}$ & $66.59^{\mathrm{e}}$ & ------- \\
\hline
\end{tabular}




\section{Effect of sample mass of JCFs on performance indicators}

The variable of sample mass was studied with batch system under optimal operation conditions for rotational speed of $600 \mathrm{rpm}(6.283 \mathrm{~m} / \mathrm{s})$ and clearance of $12 \mathrm{~mm}$ to investigate the effect of sample mass (250, $500,750,1000,1250$ and $1500 \mathrm{~g}$ ) on shelling efficiency, \%-age of broken seeds, $\%$-age of intact seeds, $\%$-age of unshelled fruits (unshelled whole fruits and partially shelled), \%-age of shells with dust, productivity of machine, power consumption, specific energy requirement and level of noise emitted from machine.

For shelling efficiency under tested sample mass range: Duncan's test in Table 5 showed that the mean effect of sample mass on shelling efficiency (\%). The mean values of shelling efficiency are not significantly (at 5\% level "P > 0.05") when increasing the sample mass from 250 to $1000 \mathrm{~g}$ while; the mean values of shelling efficiency decreased significantly (at $5 \%$ level "P < 0.05 ") from 95.90 to $93.89 \%$ with increasing the sample mass from 1000 to $1500 \mathrm{~g}$ as shown in Fig. 6. Therefore; the optimum value of the mass of sample is $1000 \mathrm{~g}$ for the feeding of shelling machine can achieve $95.90 \%$ shelling efficiency. At this value $1000 \mathrm{~g}$; the $\%$-age of unshelled fruits, $\%$-age of intact seeds and $\%$-age of shells with dust were 4.10, 57.93 and 37.00, resp.

Table 5: Duncan's test for effect of tested masses on shelling efficiency, broken seeds, machine productivity and power consumption.

\begin{tabular}{lcccccc}
\hline \hline $\mathbf{M s},(\mathbf{g})$ & $\mathbf{2 5 0}$ & $\mathbf{5 0 0}$ & $\mathbf{7 5 0}$ & $\mathbf{1 0 0 0}$ & $\mathbf{1 2 5 0}$ & $\mathbf{1 5 0 0}$ \\
\hline \hline $\boldsymbol{\eta}_{\mathbf{S h}},(\boldsymbol{\%})$. & $96.60^{\mathrm{c}}$ & $95.56^{\mathrm{bc}}$ & $96.19^{\mathrm{c}}$ & $95.90^{\mathrm{c}}$ & $94.47^{\mathrm{ab}}$ & $93.89^{\mathrm{a}}$ \\
\hline $\mathbf{P}_{\mathbf{B S}},(\boldsymbol{\%})$. & $0.43^{\mathrm{a}}$ & $0.21^{\mathrm{a}}$ & $0.42^{\mathrm{a}}$ & $0.43^{\mathrm{a}}$ & $0.40^{\mathrm{a}}$ & $0.48^{\mathrm{a}}$ \\
\hline $\mathbf{Q}, \mathbf{( k g} / \mathbf{h})$. & $111.69^{\mathrm{a}}$ & $180.53^{\mathrm{b}}$ & $212.91^{\mathrm{cd}}$ & $226.08^{\mathrm{d}}$ & $197.17^{\mathrm{bc}}$ & $215.22^{\mathrm{cd}}$ \\
\hline $\mathbf{P},(\mathbf{W})$. & $666.18^{\mathrm{a}}$ & $687.65^{\mathrm{bc}}$ & $696.06^{\mathrm{c}}$ & $694.95^{\mathrm{c}}$ & $674.79^{\mathrm{ab}}$ & $670.23^{\mathrm{a}}$ \\
\hline \hline
\end{tabular}

For the \%-age of broken seeds under tested sample mass range: Duncan's test in Table 5 showed that the mean effect of sample mass on the $\%$-age of broken seeds. The mean values of broken seeds are not significantly affected (at 5\% level "P > 0.05") and the \%-age of broken seeds was $0.43 \%$ at mass of $1000 \mathrm{~g}$. 


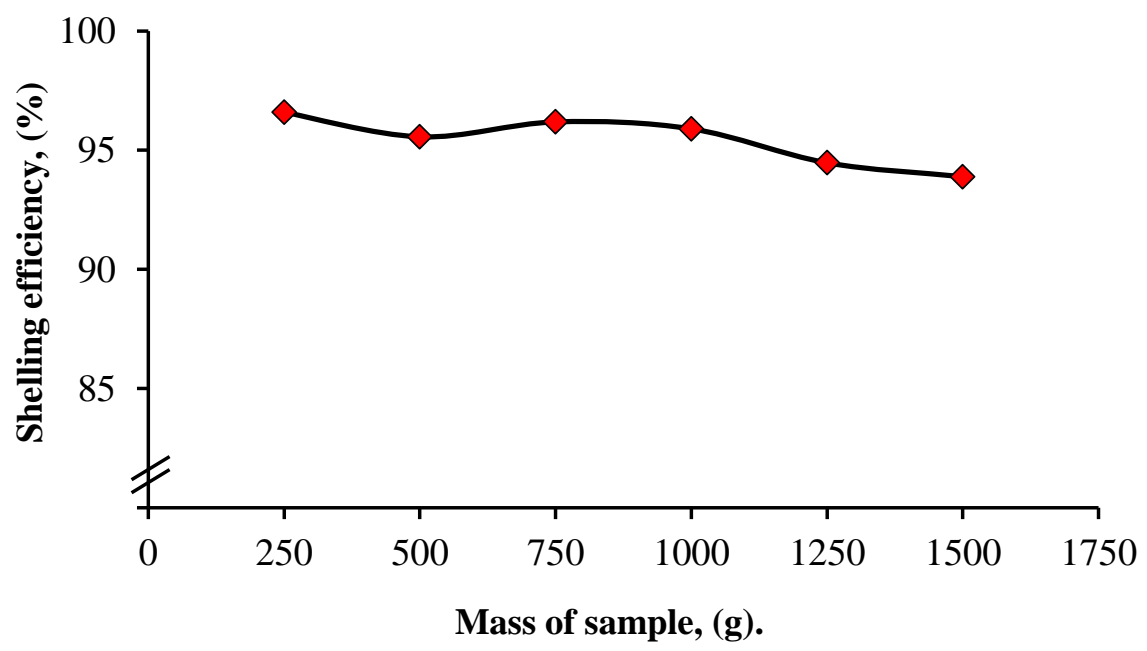

Fig. 6: Effect of tested sample mass on shelling efficiency at rotational speed of $600 \mathrm{rpm}$ and clearance of $12 \mathrm{~mm}$.

For productivity of machine: Fig. 7 shows the relationship between productivity of machine $(\mathrm{kg} / \mathrm{h})$ and sample mass used in shelling process under tested masses: 250, 500, 750, 1000, 1250 and $1500 \mathrm{~g}$ of JCFs. The productivity of machine was significantly different (at 5\% level "P $<0.05 ")$ as shown in Table 5.

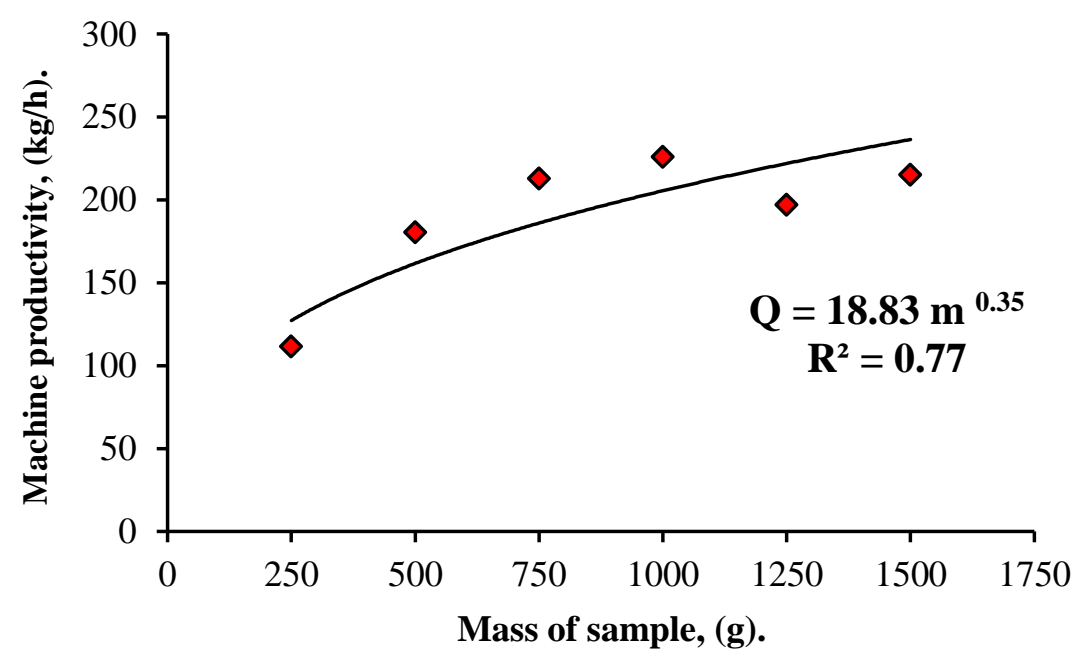

Fig. 7: Effect of sample mass on machine productivity at rotational speed of $600 \mathrm{rpm}$ and clearance of $12 \mathrm{~mm}$.

The productivity increased from 111.69 to $260.08 \mathrm{~kg} / \mathrm{h}$ when increasing the sample mass from 250 to $1000 \mathrm{~g}$, then dropped to 197.17 and 215.23 $\mathrm{kg} / \mathrm{h}$ at sample mass of 1250 and $1500 \mathrm{~g}$, resp. The relationship between 
productivity of machine and mass of sample can be expressed as a power function by the following regression equation:

$$
Q=18.83 m^{0.35} \ldots \ldots \ldots\left(R^{2}=0.77\right)
$$

The highest value of machine productivity was $226.08 \pm 7.22 \mathrm{~kg} / \mathrm{h}$ at sample mass of $1000 \mathrm{~g}$. Meanwhile; the manual shelling of JCFs was carried three times using sample of $250 \mathrm{~g}$. The results indicated that the productivity of manual shelling was $1.44 \pm 0.20 \mathrm{~kg} / \mathrm{h}$.

For power and specific energy requirements: Duncan's test in Table 5 showed that the mean effect of sample mass on the power consumption (W). The mean values of power consumption increased significantly (at $5 \%$ level "P < 0.05 ") from 666.18 to $687.65 \mathrm{~W}$ with increasing the sample mass from 250 to $500 \mathrm{~g}$ and not significantly (at $5 \%$ level "P > 0.05 ") when increasing the sample mass from 500 to $1000 \mathrm{~g}$. Meanwhile; the mean values of power consumption decreased significantly (at 5\% level "P < 0.05 ") from 694.95 to $670.23 \mathrm{~W}$ with increasing the sample mass from 1000 to $1500 \mathrm{~g}$.

Fig. 8 shows the relationship between specific energy requirement (ES, W.h/kg) and sample mass (g) used in shelling process under tested masses: 250, 500, 750, 1000, 1250 and $1500 \mathrm{~g}$ of JCFs. The lowest and highest values of specific energy requirement were 3.07 and $6.03 \mathrm{~W} . \mathrm{h} / \mathrm{kg}$ at sample mass of 1000 and $250 \mathrm{~g}$, resp.

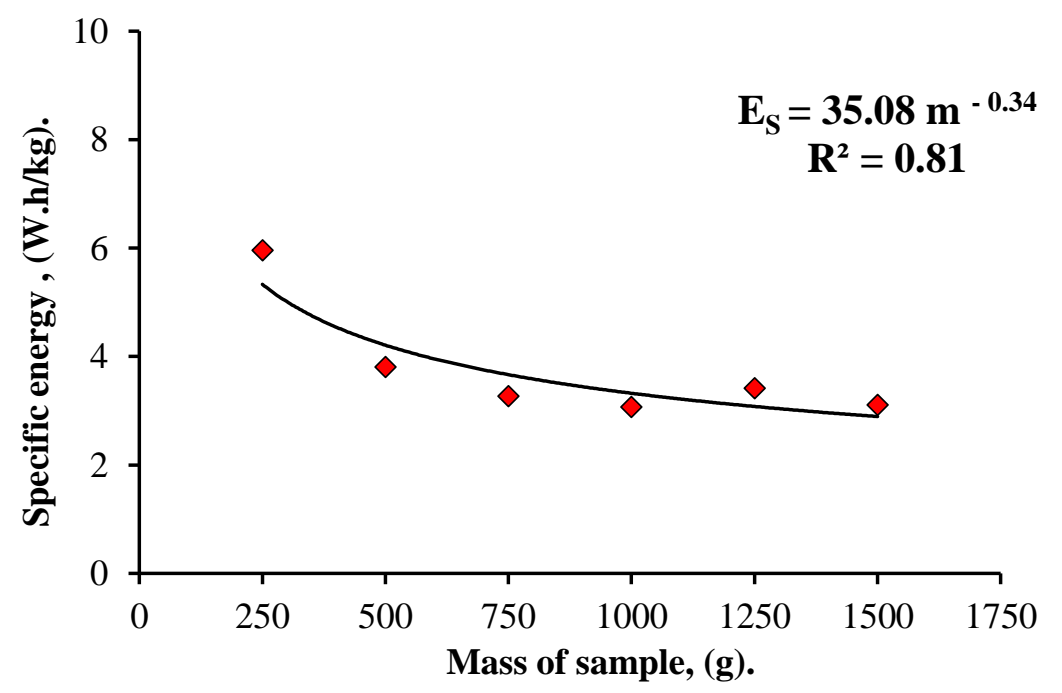

Fig. 8: Effect of sample mass on the specific energy requirement at rotational speed of $600 \mathrm{rpm}$ and clearance of $12 \mathrm{~mm}$. 
The relationship between specific energy and mass of sample can be expressed as a power function by the following regression equation:

$$
E_{S}=35.08 m^{-0.34} \ldots \ldots \ldots\left(R^{2}=0.81\right)
$$

For level of emitted noise from shelling machine: The average levels of noise were 95.63 and $96.81 \mathrm{~dB}$ without load "before putting the fruits" and with load (during the shelling process), resp., as shown in Table 6. The level of noise was $97.2 \mathrm{~dB}$ at sample mass of $1000 \mathrm{~g}$ under rotational speed of $600 \mathrm{rpm}$ and clearance of $12 \mathrm{~mm}$. This value of emitted noise level $(97.2 \mathrm{~dB})$ is like the obtained result by (Mislaini et al., 2015). They found that the average emitted noise level from corn sheller is $97.07 \mathrm{~dB}$. The obtained result for emitted noise from developed machine is high in comparison with the standard value $(90 \mathrm{~dB})$ at exposure period $8 \mathrm{~h} / \mathrm{day}$ according to $(\boldsymbol{E E L}, 1994)$. So; the emitted noise from the developed machine should be reduced with the following methods: such as; insulation of power transmission parts (sprocket wheels and chains) and chamber of shelling, using an electric motor with a speed control (Inverter) to reduce the three power transmission stages to one, in addition to operating the shelling machine in open air and operator of machine can use hearing or ear protection. These processes may be reducing the noise level to the permissible limits to avoid the harmful effects for health of operator.

Table 6: Average values of emitted noise level from developed machine.

\begin{tabular}{ccc}
\hline Mass of sample, & \multicolumn{2}{c}{ Emitted noise, $(\mathbf{d B})$} \\
\cline { 2 - 3 }$(\mathbf{g})$ & With load & without load \\
\hline 250 & $97.00 \pm 0.00$ & \\
500 & $97.07 \pm 0.12$ & \\
750 & $96.93 \pm 0.40$ & \\
1000 & $97.20 \pm 0.72$ & \\
1250 & $96.67 \pm 0.58$ & \\
1500 & $96.00 \pm 0.00$ & $\mathbf{9 5 . 6 3} \pm \mathbf{0 . 4 9}$ \\
\hline Average & $\mathbf{9 6 . 8 1} \pm \mathbf{0 . 5 4}$ & \\
\hline
\end{tabular}

\section{CONCLUSION AND RECOMMENDATIONS}

- The obtained results were summarized as follows:

The suggested design of the prototype achieved high efficiency in shelling of JCFs. Under the tested speed range [200 (2.094) to $600 \mathrm{rpm}$ $(6.283 \mathrm{~m} / \mathrm{s})]$ and the tested clearance range [12 to $16 \mathrm{~mm}$ ], the shelling 
efficiency of JCFs gradually increased with increasing the tested speeds and decreasing the clearances. The speed of $600 \mathrm{rpm}$ is optimal for the shelling efficiency at clearance of $12 \mathrm{~mm}$.

$>$ Under the tested sample mass range [250 to $1500 \mathrm{~g}$ ], the mass sample of $1000 \mathrm{~g}$ is optimal for shelling efficiency and productivity of machine, whereas; the mean values of \%-age of broken seeds was not significant under the tested sample mass range.

Also; the results revealed that the highest value of machine productivity was $226.08 \mathrm{~kg} / \mathrm{h}$. Meanwhile; the average shelling efficiency, \%-age of broken seeds, unshelled fruits and intact seeds were 95.90, 0.43, 4.10 and $57.93 \%$, resp. Further; the mean values of power consumption and specific energy requirement were $694.95 \mathrm{~W}$ and $3.07 \mathrm{~W} . \mathrm{h} / \mathrm{kg}$, resp. In addition, the level of emitted noise from developed machine was $97.2 \mathrm{~dB}$ and should be reduced to the permissible limits $(90 \mathrm{~dB})$ at exposure period of $8 \mathrm{~h} /$ day.

Performance evaluating of the suggested shelling/cracking machine in the future for shelling of agricultural products such as: Jatropha seeds, Sunflower seeds, Peanut pods, Castor fruits...etc. In addition, investigation of possibility cracking of fruits pits for extracting the kernels such as: Peach, Apricot, Plum, Walnuts, Almonds, Hazelnuts... etc.

$>$ In case of specialization; It is possible dividing the constant conical part in shelling/cracking chamber into three parts or more; to fit with the size of fruits or seeds (small, medium and large) which need to shelling or cracking process for reducing the cost of machine manufacturing.

Possibility investigation of developing the suggested shelling/cracking machine with addition a blower air and vibrating sieves for separating process. Further; improvement of power transmission using electric motor with a speed control (Inverter).

\section{REFERENCES}

Cramer, J. (2010). The Jatropha handbook from cultivation to application. (Netherlands): (http://www.slideshare.net/QZ1/w1y47). EEL, (1994). Egyptian Environmental Low - Number "4".

Kheiralla, A. F.; E. H. Tola; A. N. Korsha and A. Y. Eltigani (2015). Development and evaluation of a Jatropha seeds shelling machine 
for biofuel production. (Sudan); Am.-Eurasian J. Agric. \& Environ. Sci., 15 (4): 630 - 639.

Kheiralla, A.; E. Tola; A. Korsha and A. Eltigani (2016). Development and evaluation of a Jatropha husking machine. (Sudan); ARPN "J. of Ag. and Bio. Sci., 11 (3): 88 - 99.

Krishnan, P. R. and M. Paramathma (2009). Potentials and Jatropha species wealth of India, Current Science, 97(7): 1000-1004.

Kumar, A. and S. Sharma (2008). An evaluation of multipurpose oil seed crop for industrial uses (Jatropha curcas L.): A review. (India); Industrial Crops and Products, 28 (1): 1 - 10.

Lim, B. Y.; R. Shamsudin and R. Yunus (2014). Development and testing of a Jatropha fruit shelling process for shell-free kernel recovery in biodiesel production. (Malaysia); Biosys. Eng., 121: 46 $-55$.

Mislaini, Santosa and Widyawati (2015). Study of techno-economic of corn sheller type MPJ-01-TEP-2014 design of study program Agric. Eng. Univ. Andalas. (Indonesia); I.J.A.S.E.I.T., 5 (1): 23 26.

Mousa, A. M. (2015). Engineering factors affecting production of biodiesel from used vegetable oil using a simple unit. $\mathrm{PhD}$. Thesis, Fac. of Agric., Al-Azhar Univ., Cairo, (Egypt). PP: 1.

Mousa, A. M.; N. S. Elkaoud and S. H. Dosoky (2016). Physical, mechanical and aerodynamic properties of Jatropha seeds. (Egypt) - Misr J. Ag. Eng., 33(4): 1477 - 1496.

Pradhan, R. C.; S. N. Naik; N. Bhatnagar and V. K. Vijay (2010). Design, development and testing of hand-operated decorticator for Jatropha fruit. (India); App. En., 87: 762 - 768.

Salawu, A. T.; M. L. Suleiman and M. Isiaka (2013). Physical properties of Jatropha curcas seed. (Nigeria); EJPAU “Agr. Eng."; 16 (4), \# 07. - http://www.ejpau.media.pl/volume16/issue4/art07.html

Ting, R. P.; E. V. Casas; E. K. Peralta and J. C. Elauria (2012). Design, fabrication and optimization of Jatropha sheller. (Philippines); I.J.O.C.: Theories \& Applications, 2 (2): 113-127.

Werby, R. A. and A. M. Mousa (2016). Some physical and mechanical properties of Jatropha fruits. (Egypt); Misr J. Ag. Eng., 33 (2): $475-490$. 


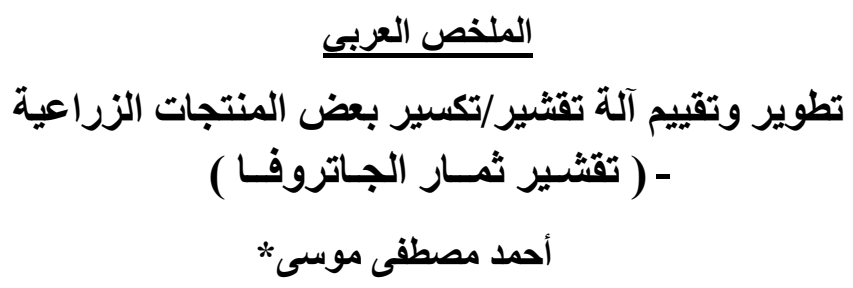

تهدف هذه الدر اسة إلى تطوير آلة تقشير أو تكسير تصلح لبعض المنتجات الزراعية، كما تم

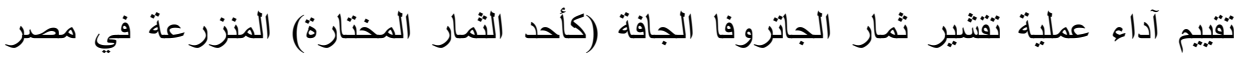
باستخدام الآلة المطورة و جميع تجارب تقشير ثمار الجاتروفا تمت عند محتوى رطوبي 0ـ, 1 1\% على أساس الوزن الجاف ـ تم تصنيع الآلة وإجراء التجارب بكلية الهندسة الزراعية بالقاهرة - جامعة الأزهر.

- و تم دراسة المتغيرات التالية:

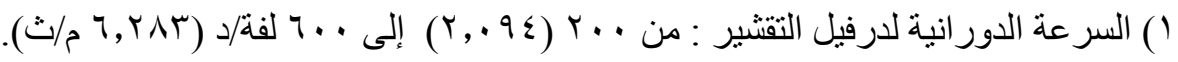

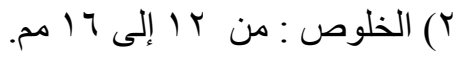

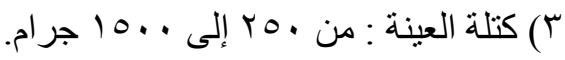
و كاتت النتائج المتحصل عليها كالتالى:

ا . حقق النموذج الأولي للآلة المقترحة كفاءة عالية في تقشير ثمار الجاتروفا.

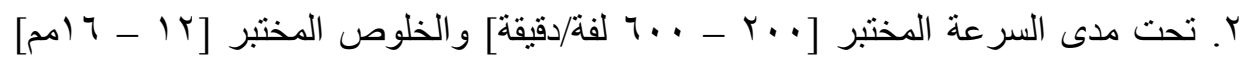

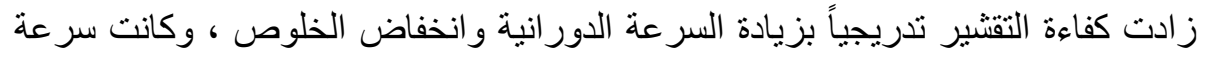

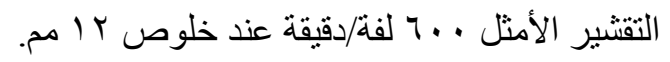
ب. أظهرت النتائج أن كتلة عينة ثمار الجاتروفا (.... (. جرام) هي الأمثل لكفاءة التقشير وإنتاجية الآلة ، و أنه لايوجد فرق معنوي في نسبة البذور المكسورة تحت مدى كتلة العينة

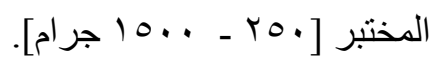

ع. كما بينت النتائج أن أعلى قيمة لإنتاجية الآلة كانت 1 • , بr و كج/ساعة عند كفاءة تقشير

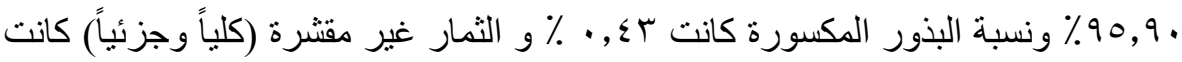

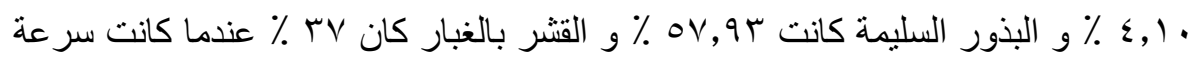

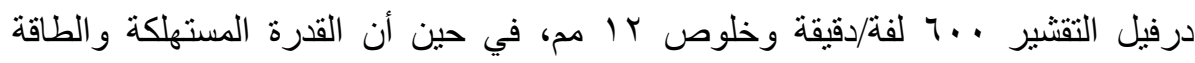

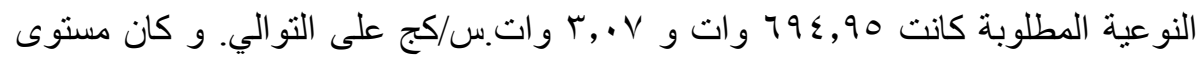

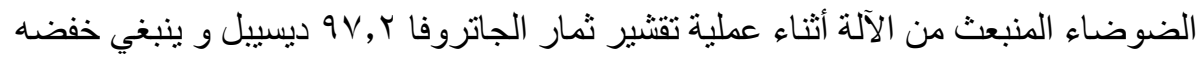
للحدود المسموح بها ( • (9 ديسيبل) عند فترة تعرض مقدار ها م ساعات عمل/ يوم.

*مدرس: قسم هندة الآلات والقوى الزراعية - كلية الهندة الزراعية - جامعة الأزهر - القاهرة - مصر. 